AndRZEJ PIASECKI $^{1}$

\title{
Administracja polska wobec problemu migrantów po 2015 r. Kluczowe kwestie prawne i polityczne
}

\section{Wprowadzenie}

Od dłuższego czasu w Polsce trwa dyskusja na temat przyjęcia uchodźców i wszelkiego rodzaju emigrantów z krajów spoza Unii Europejskiej. Wzbudza ona bardzo wiele kontrowersji zarówno wśród polityków, dziennikarzy czy publicystów, jak i w całym społeczeństwie. Głównym problemem jest brak zgody części środowisk politycznych, które najczęściej kształtują opinię publiczną, na ustalenia wewnątrzunijne i zapisy traktatowe dotyczące relokacji emigrantów. Większość partii lewicowych (Razem, SLD, Wiosna) nawołuje do priorytetowej polityki pomocy uchodźcom, partie środka (PO, Nowoczesna) do umiarkowanej, racjonalnej pomocy, ale zgodnej z dyrektywami unijnymi, natomiast środowiska prawicowe i narodowe (PiS, SP, MW, ONR) są zdecydowanie przeciw. Aktualnie prawie cały obóz rządzący powołuje się na tzw. brak suwerenności państwa spowodowany prawodawstwem unijnym oraz znaczne obciążenia i zagrożenia dla Polski będącej „granicznym” państwem Unii Europejskiej i demokratycznej Europy.

Rzeczpospolita Polska większości publicystów i specjalistów z tego zakresu częściej kojarzy się raczej z wypędzeniami niż z przyjmowaniem uchodźców, szczególnie w okresie Polski Ludowej (przesiedlenia ludności pochodzenia niemieckiego, Ukraińców i Łemków, emigracja osób pochodzenia żydowskiego w 1968 r. itp.). Szczególnie dobitnie podsumowuje to M. Princ, który pisze, że „Rzeczpospolita Polska była przez wieki rozpoznawana jako miejsce, w którym wielu doznawało wytchnienia po trudach i prześladowaniach w innych miejscach, także Europy. Świadczyć o tym może określenie Polanya (z hebr. Polska), które jednocześnie oznacza: Tutaj mieszka Bóg, a słowo Polin - Tutaj odpocznij. Z drugiej strony należy podnieść, że w XIX i XX w. najwięcej osób opuściło nasz kraj nie z własnej woli,

1 Prof. dr hab. Andrzej Piasecki, Instytut Prawa, Administracji i Ekonomii, Uniwersytet Pedagogiczny im. Komisji Edukacji Narodowej w Krakowie. 
uzyskując schronienie w innych państwach. Dotyczyło to zarówno okresu zaborów, jak i sytuacji politycznej po II wojnie światowej”2.

Poniżej przedstawione zostaną kluczowe aspekty prawne oraz działania i stanowiska polskich władz i polskiej administracji dotyczące tematyki fali migracyjno-uchodźczej od 2015 r. Zakres czasowy analizy został określony nieprzypadkowo, również niektórzy historycy uznają 2015 r., który był szczytowym momentem narastania fali uchodźców w Europie, za ważną cezurę czasową dla swoich ustaleń ${ }^{3}$.

\section{Migranci w Polsce po 1989 r. - zarys przemian}

Odzyskanie niepodległości oraz budowa demokracji i wolnego rynku to procesy, które po 1989 r. miały wpływ na wszystkie sprawy publiczne w Polsce, także na politykę migracyjną. W latach 1992-2203 o nadanie statusu uchodźcy ubiegało się w naszym kraju 37313 osób, a otrzymało go 1920 . Największe grupy migrantów pochodziły z krajów objętych konfliktami: Bośni i Hercegowiny (1992-1993), Armenii (1994-1999), Sri Lanki (1997) oraz Rosji (Czeczeńcy). Narodowy spis powszechny z 2002 r. wyodrębniał grupę cudzoziemców (62 tys. osób). Byli to głównie ludzie młodzi (41\% w wieku 25-44 lata), mieszkający w miastach (73\%), w większości przebywali w Polsce ponad rok (71\%). Pod wpływem zachodzących przemian w 2011 r. powstał Urząd do Spraw Repatriacji i Cudzoziemców, a dwa lata później po raz pierwszy przeprowadzono abolicję dla cudzoziemców ${ }^{4}$.

Odrębnym problemem była repatriacja, czyli powrót Polaków (głównie z krajów byłego ZSRR) do Polski. W latach 1989-2002 według spisu powszechnego było to około 70 tys. osób. W XXI w. status Polaków przebywających za wschodnimi granicami kraju pomogła unormować Karta Polaka (wydawana od 2007 r.), dokument potwierdzający przynależność do narodu polskiego osób nieposiadających obywatelstwa polskiego ${ }^{5}$. Najbardziej powszechnym zjawiskiem kształtującym stosunek do problemu migracji były jednak wyjazdy Polaków w poszukiwaniu pracy za granicą po przystąpieniu do Unii Europejskiej. Zjawisko to miało charakter najbardziej

2 M. Princ, Ochrona uchodźców w Polsce [w:] Uchodźcy w Europie. Uwarunkowania, istota, następstwa, K.A Wojtaszczyk, J. Szymańska (red.), Warszawa 2017, s. 590.

3 A. Piasecki, R. Michalak, Polska 1945-2015, Warszawa 2016; A. Dudek, Historia polityczna Polski 1989-2015, Kraków 2015; M. Gędek, Nieznane dzieje Polski 19432015, Warszawa 2016.

4 K. Andrejuk, A. Fihl, Migracje w Polsce w okresie 1989-2004 [w:] 25 wykładów o migracjach, M. Lesińska. M. Okólski (red.), Warszawa 2018, s. 205.

5 Ustawa z dnia 7 września 2007 r. o Karcie Polaka, tekst jedn.: Dz. U. z 2019 r. poz. $1598 \mathrm{ze} \mathrm{zm}$. 
masowy w dziejach Polski, według szacunkowych obliczeń objęło około 2,52 mln ludzi (lata 2004-2017).

\section{Główne normy prawne oraz formy pomocy obowiązujące w Rzeczypospolitej Polskiej wobec migrantów}

W porządku prawnym Rzeczypospolitej Polskiej kilka aktów normatywnych gwarantuje uchodźcom wystarczającą pomoc w udzielaniu schronienia i długoterminowej opieki.

Do głównych aktów normatywnych należy zaliczyć:

1) Konstytucję Rzeczypospolitej Polskiej z dnia 2 kwietnia 1997 r.7, której dwa artykuły w dość lakoniczny sposób poruszają sprawy ochrony migrantów; chodzi o art. 38 poświęcony prawnej ochronie życia oraz art. 56 o statusie uchodźcy. W kwestiach szczegółowych Konstytucja odsyła do ustaw oraz obowiązujących Polskę umów międzynarodowych;

2) Konwencję dotyczącą statusu uchodźców, sporządzoną w Genewie dnia 28 lipca 1951 r. ${ }^{8}$ Konwencja została ratyfikowana przez Rzeczpospolitą Polską w 1991 r. i weszła w życie pod koniec tego roku. Zgodnie z hierarchią aktów prawnych RP jako umowa międzynarodowa zajmuje ona miejsce za Konstytucją i reguluje dość wyczerpująco kwestie praw człowieka, pomocy uchodźcom oraz współpracy międzynarodowej przy udzielaniu tej pomocy ${ }^{9}$;

3) ustawę z dnia 13 czerwca 2003 r. o udzielaniu cudzoziemcom ochrony na terytorium Rzeczypospolitej Polskiej ${ }^{10}$, która bardzo szczegółowo reguluje zasady, warunki i tryb udzielania cudzoziemcom pomocy na terytorium Polski, a także wyznacza organy właściwe w tych sprawach. Prawo Rzeczypospolitej Polskiej przewiduje cztery różne formy pomocy obywatelom innych państw, których egzystencja lub bezpieczeństwo są bardziej lub mniej zagrożone w rodzimych krajach. Należą do nich:

1) Status uchodźcy. Zgodnie z art. 13 ust. 1 konwencji genewskiej określono, że „Cudzoziemcowi nadaje się status uchodźcy, jeżeli na skutek uzasadnionej obawy przed prześladowaniem w kraju pochodzenia z powodu rasy, religii, narodowości, przekonań politycznych lub przynależności do określonej grupy społecznej nie może lub nie chce korzystać z ochrony tego kraju”. Oczywiście prawo to dotyczy również dzieci cudzoziemca, o czym mówi ust. 2.

6 M.P. Garapiach, I. Grabowska, E. Jaźwińska, Migracje poakcesyjne z Polski [w:] 25 wykładów o migracjach..., s. 218.

7 Dz.U. z 1997 r. Nr 78, poz. 483 ze zm.

8 Dz.U. z 1991 r. Nr 119, poz. 515 ze zm., dalej: konwencja genewska.

9 M. Zdanowicz, P. Zdanowicz, Prawo międzynarodowe a migracje [w:] 25 wykładów o migracjach..., passim.

10 Tekst jedn.: Dz.U. z 2019 r. poz. 1666 ze zm. 
2) Azyl. najważniejszym akcie prawnym RP - Konstytucji RP w art. 56 uwzględniono zarówno kwestię statusu uchodźcy, jak i azylu na terytorium RP: „1. Cudzoziemcy mogą korzystać z prawa azylu w Rzeczypospolitej Polskiej na zasadach określonych w ustawie. 2. Cudzoziemcowi, który w Rzeczypospolitej Polskiej poszukuje ochrony przed prześladowaniem, może być przyznany status uchodźcy zgodnie z wiążącymi Rzeczpospolitą Polską umowami międzynarodowymi”. W sprawie zasad i szczegółów Konstytucja odsyła do właściwej ustawy. Artykuł 90 ust. 1 ustawy o udzielaniu cudzoziemcom ochrony stanowi, że: „Cudzoziemcowi można, na jego wniosek, udzielić azylu w Rzeczypospolitej Polskiej, gdy jest to niezbędne do zapewnienia mu ochrony oraz gdy przemawia za tym ważny interes Rzeczypospolitej Polskiej”.

3) Ochrona czasowa - przypomina status uchodźcy, lecz jest traktowana krótkoterminowo. W myśl art. 106 ust. 1 ustawy o udzielaniu cudzoziemcom ochrony: „Cudzoziemcom masowo przybywającym do Rzeczypospolitej Polskiej, którzy opuścili swój kraj pochodzenia lub określony obszar geograficzny, z powodu obcej inwazji, wojny, wojny domowej, konfliktów etnicznych lub rażących naruszeń praw człowieka, można udzielić ochrony czasowej na terytorium Rzeczypospolitej Polskiej bez względu na to, czy ich przybycie miało charakter spontaniczny, czy też było wynikiem pomocy udzielonej im przez Rzeczpospolitą Polską lub społeczność międzynarodową". Według ust. 2 tego przepisu: „Ochrony czasowej udziela się do chwili, gdy możliwy stanie się powrót cudzoziemców do uprzedniego miejsca ich zamieszkania, jednakże nie dłużej niż na okres roku”.

4) Ochrona uzupełniająca. Ostatni wariant prawny uzupełnia poprzednie przez możliwość udzielenia pomocy cudzoziemcowi, który nie spełnia części warunków niezbędnych do statusów wcześniej opisanych. Zgodnie $\mathrm{z}$ art. 15 ustawy o udzielaniu cudzoziemcom ochrony „Cudzoziemcowi, który nie spełnia warunków do nadania statusu uchodźcy, udziela się ochrony uzupełniającej, w przypadku gdy powrót do kraju pochodzenia może narazić go na rzeczywiste ryzyko doznania poważnej krzywdy".

Porządek prawny Polski, poza powyższymi unormowaniami, nie uwzględnia innych rodzajów migracji, np. na tle zarobkowym spoza Unii Europejskiej. Dla obywateli krajów nieunijnych przewidziane są wyłącznie wizy turystyczne lub służbowe.

\section{4. „Samoobrona” państw Grupy Wyszehradzkiej przed obowiązkową relokacją uchodźców}

Grupa Wyszehradzka (V4) powstała 15 lutego 1991 r. w wyniku podpisania wspólnej trójstronnej deklaracji przez prezydentów Polski, Czechosłowacji 
i premiera Węgier. Deklaracja określała cele i warunki współpracy, szczególnie w zakresie kultury, nauki, edukacji, wymiany informacji, rozbudowy infrastruktury transportowej i bezpieczeństwa energetycznego w regionie. Wskutek rozpadu Czechosłowacji 1 stycznia 1993 r. członkami grupy stały się Czechy i Słowacja. Według polskiego rządu Grupa Wyszehradzka jest „nieformalną regionalną formą współpracy”"11, a jedyną w pełni zinstytucjonalizowaną jej częścią jest Międzynarodowy Fundusz Wyszehradzki (IVF). Przewodnictwo w grupie trwa rok i przyznawane jest na zasadzie rotacji.

W ramach Grupy Wyszehradzkiej państwa członkowskie próbują wypracować wspólne stanowisko wobec problemów dyskutowanych na obradach Unii Europejskiej. Podobnie było w przypadku problemu migracyjnego, który zaczął poważnie nasilać się od 2015 r. Podczas szczytu Grupy Wyszehradzkiej w Pradze, zorganizowanego 15 lutego 2016 r. z okazji 25. rocznicy jej istnienia, premierzy państw członkowskich przyjęli następujące oświadczenie: „Premierzy państw Grupy Wyszehradzkiej wyrazili pełne poparcie dla środków przyjętych na szczeblu Unii Europejskiej w celu bardziej skutecznej ochrony granic zewnętrznych, w tym wzmocnionej współpracy z państwami trzecimi na okoliczność ich negatywnego stanowiska w sprawie stałego mechanizmu automatycznej relokacji. Omówili również ewentualne dalsze kroki i praktyczne działania zmierzające do stabilizacji sytuacji na zachodniobałkańskim szlaku migracji, intensyfikację komunikacji pomiędzy zainteresowanymi państwami, wzmocnienie bezpieczeństwa oraz zapobieganie napięciom w regionie"12.

$\mathrm{W}$ powyższym oświadczeniu wyrażono mocny i zdecydowany sprzeciw wobec unijnego pomysłu automatycznej, narzuconej relokacji. Mogło ono zostać wypracowane dopiero na przełomie 2015 i 2016 r., ponieważ wcześniej nie było w tej kwestii całkowitej solidarności. O ile Czechy, Słowacja i Węgry od początku były przeciwne rozwiązaniom unijnym, to w początkowym okresie Polska zaakceptowała plan UE. Pomimo obaw społeczeństwa i pewnego strachu, często spowodowanego brakiem wiedzy i znajomości kultury innych narodów, szeroko dyskutowanych w mediach, rząd Ewy Kopacz (PO) zaakceptował kwoty relokacji do poszczególnych krajów, w tym do Polski. Radykalna zmiana nastąpiła pod koniec 2015 r., kiedy po przegranych przez Platformę Obywatelską wyborach parlamentarnych do władzy doszło Prawo i Sprawiedliwość. Nowy rząd z premier Beatą Szydło od początku cechował się eurosceptycyzmem oraz zdecydowaną wrogością do uchodźców, w szczególności tych z krajów islamskich.

Na dwóch kolejnych szczytach GW, 8 czerwca 2016 r. w Pradze i 21 lipca 2016 r. w Warszawie członkowie grupy wzmocnili i podtrzymali swoje stanowisko wobec problemu uchodźców. Jak podaje A. Czyż, „Państwa Gru-

11 Zob. https://www.msz.gov.pl/pl/polityka_zagraniczna/europa/grupa_wyszehradzka/ (dostęp: 5.09.2019).

12 Joint Statement on Migration, Praga, 2016, http://www.visegradgroup.eu/calendar/2016/jointstatementon (dostęp: 25.11.2016). 
py Wyszehradzkiej nadal podtrzymywały swoje stanowisko, iż propozycje oparte na obowiązkowym systemie redystrybucji azylantów działają jako czynnik przyciągający, a dodatkowo dzielący państwa członkowskie (oraz ich społeczeństwa), ponadto system obowiązkowej relokacji nie działa w rzeczywistości. Podczas kolejnego szczytu (...) podkreślano, jak potrzebny jest konsens europejski w sprawie powstrzymania presji migracyjnej, ale ponadto zwracano uwagę, jak ważne jest, aby skoncentrować wysiłki na efektywnym sprawdzaniu, kto rzeczywiście potrzebuje pomocy, a kto tylko próbuje poprawić swój status ekonomiczny"13.

Warto w tym miejscu podjąć próbę wyjaśnienia takiego podejścia rządów państw Grupy Wyszehradzkiej, nie w celu usprawiedliwiania ich, lecz ułatwienia zrozumienia szczególnej sytuacji, w jakiej się znajdują.

Wszystkie cztery państwa stanowią byłe państwa tzw. obozu demokracji ludowej czy tzw. państwa satelickie ZSRR. Po upadku ZSRR i w pewnym sensie wyzwoleniu się, a na pewno uzyskaniu niezależności przez te państwa na przełomie lat 80. i 90. XX w., stanęły one przed szeregiem bardzo trudnych wyzwań. Do niektórych należą zewnętrzne, takie jak wstąpienie do struktur NATO czy UE po spełnieniu niezbędnych warunków, ale dużo trudniejsze i bardziej priorytetowe okazały się wyzwania natury wewnętrznej i to na dwóch płaszczyznach. Pierwsza obejmuje sprawy formalne, które trzeba załatwić przy transformacji ustrojowej, takie jak konstrukcja nowych norm prawnych regulujących sprawy państwa i obywateli, organizacja wolnego rynku i gospodarki rynkowej, zmiany w resortach siłowych czy sądownictwie. Szczególnie trudna okazała się kwestia prywatyzacji oraz przywrócenia majątku zagrabionego przez państwo socjalistyczne prawowitym właścicielom. Część tych problemów pozostaje nieuregulowana do dziś. Druga płaszczyzna to sprawy mentalne, takie jak wytrzebienie nawyków społecznych nabytych przez okres prawie 40 lat PRL, czyli nepotyzmu, łapówkarstwa, próżniactwa, leserstwa itp. Konieczne okazało się też stworzenie społeczeństwa obywatelskiego, organizacji pomocowych i samorządu. Będąc obywatelem jednego z tych krajów, odnosi się wrażenie, że transformacja systemowa może się tylko zacząć, a nie kończy się nigdy, ponieważ zawsze jest jeszcze wiele do zrobienia. Takie państwa UE jak Francja, Austria i Wielka Brytania nie są obciążone podobnymi zależnościami i zaległościami, więc po pierwsze - stać je na więcej, a po drugie - mają trudności ze zrozumieniem odmiennej sytuacji innych państw.

Po ogólnej wzmiance obrazującej sytuację (polityczną, gospodarczą i historyczną) państw Grupy Wyszehradzkiej można jeszcze naświetlić skomplikowane uwarunkowania wewnętrzne poszczególnych jej członków, co najbardziej uzasadni sprzeciw wobec relokacji. Specjaliści zajmujący się tematyką uchodźstwa i migracji (w szczególności politycznych, niezarob-

13 A. Czyż, Państwa Grupy Wyszehradzkiej wobec kryzysu migracyjnego, „Studia Politicae Universitatis Silesiensis” 2017, t. 18, s. 151-152. 
kowych) wyszczególnili siedem głównych szlaków migracji, z którymi mamy do czynienia w ostatnim dziesięcioleciu (od 2010 r.):

1) szlak zachodnioafrykański (z Maroka na Wyspy Kanaryjskie),

2) szlak centralny śródziemnomorski (z Algierii, Tunezji i Libii do Włoch),

3) szlak zachodni śródziemnomorski (z Maroka do Hiszpanii),

4) szlak wschodni śródziemnomorski (z Turcji do Grecji, Włoch, na Cypr),

5) szlak bałkański (z Syrii do Węgier i Chorwacji),

6) szlak wschodnioeuropejski (z Ukrainy do Polski),

7) szlak arktyczny (z Rosji do Finlandii i Norwegii) ${ }^{14}$.

Do opisu problemów państw Grupy Wyszehradzkiej zastosowanie mają dwa z nich, szlak bałkański oraz szlak wschodnio-europejski.

W najcięższej sytuacji z całej grupy znalazły się Węgry. Państwo o niewielkiej ludności niespełna $10 \mathrm{mln}$ obywateli, niezbyt dużym PKB, borykające się z niestabilnością i wewnętrznymi problemami politycznymi, kompletnie nie było przygotowane do prawie całkowitego „paraliżu granic" i jednej z największych fal uchodźców przybyłych w ostatnich latach. To właśnie przez Węgry biegnie częściowo szlak bałkański. M. Jaroszewicz i M. Gniazdowski podają, że „175-kilometrowa granica serbskowęgierska stała się jedną z najbardziej obleganych przez migrantów granic Unii Europejskiej. Wprawdzie wiosną 2015 roku udało się zmniejszyć napływ tą drogą migrantów z Kosowa i Serbii, ale w miesiącach letnich tego roku znacznie przybrała fala migrantów spoza Europy - przede wszystkim obywateli Syrii, Afganistanu i Iraku. Przedzierali się oni z Turcji przez Grecję, Macedonię i Serbię na Węgry, z nadzieją na dotarcie do państw Europy Zachodniej, głównie do Niemiec"15. Z tych powodów władze węgierskie zmuszone były do przedsięwzięcia bardzo radykalnych czynności, szeroko krytykowanych przez opinię światową i unijne instytucje. Główne decyzje, podjęte już w 2015 r., to zaostrzenie przepisów dotyczących nielegalnego przekraczania granicy, budowa na granicy z Serbią ogrodzenia z drutu kolczastego oraz zamknięcie granicy z Chorwacją. Zdecydowana i konsekwentna postawa premiera Węgier Viktora Orbána była bardzo szeroko krytykowana, jednak z punktu widzenia urzędników i ludności węgierskiej uzasadniona.

Drugim państwem Grupy z dość skomplikowaną sytuacją wewnętrzną jest Republika Słowacka. Jest najmniejszym państwem spośród całej czwórki, jej ludność szacuje się na 5,5 mln, ma dość niskie PKB, nienajlepszy teren (w dużej części górzysty), jest niezbyt uprzemysłowiona. Poziom życia mieszkańców Słowacji jest najniższy z całej czwórki. Jak twierdzą Słowacy, największym problemem powodującym taki stan rzeczy jest skład etniczny ludności. Chodzi o wysoki odsetek społeczności romskiej, wyma-

14 Zob. https://frontex.europa.eu/along-eu-borders/migratory-map/ (dostęp: 10.02.2019).

15 M. Gniazdowski, M. Jaroszewicz, Wegierska odsłona kryzysu migracyjnego. Analizy OSW, 2015, https://www.osw.waw.pl/pl/publikacje/analizy/2015-09-09/wegierska-odslona-kryzysu-migracyjnego (dostęp: 14.02.2019). 
gającej pomocy socjalnej, wśród której jest bardzo wysoki wskaźnik bezrobocia. Choć statystyki spisu powszechnego z 2001 r. szacują mniejszość romską na 2\%, zarówno specjaliści, jak i rząd słowacki kwestionują tę liczbę i podają, że stanowi ona ok. 10\%. Większość osób pochodzenia romskiego podawała się podczas spisu za Słowaków, a osoby bardziej rozpoznawalne za Węgrów (dlatego w spisie pojawiła się aż 8,5-procentowa mniejszość węgierska). Ostatecznie władze słowackie podają, że Romów żyjących na Słowacji jest około pół miliona, z czego 95\% to ludzie bezrobotni, żyjący $\mathrm{w}$ osadach przy miastach i dużych wsiach, w skrajnej nędzy ${ }^{16}$. Mając na uwadze ciężką sytuację wewnętrzną, etniczną i gospodarczą, a także wielkość kraju i liczbę populacji, można zrozumieć sprzeciw wobec obowiązku relokacji uchodźców.

Polska jest największym państwem Grupy Wyszehradzkiej, z ludnością ponad $38 \mathrm{mln}$, jedynym $\mathrm{z}$ dostępem do morza, który może przynosić liczne korzyści, i o umiarkowanym, ale nie bardzo niskim poziomie życia. Jednak to Polski właśnie dotyczy drugi wyszczególniony szlak migracji, szlak wschodnioeuropejski. Problemy wschodnich sąsiadów RP, aneksja Krymu przez Federację Rosyjską, niekończące się działania militarne separatystów rosyjskich powodują ucieczki, migracje i wszelkie inne próby ratowania się części ludności ukraińskiej. Naturalnym kierunkiem jest ucieczka z Ukrainy do Polski, zarówno jako państwa tranzytowego, jak i docelowego. Specjaliści szacują, że aktualna liczba ludności ukraińskiej w Rzeczpospolitej Polskiej to ponad 2 mln osób. Emigranci przeważnie pracują, bardzo szybko uczą się języka polskiego, a także dużo łatwiej i szybciej od innych narodów integrują się ze społecznościami lokalnymi. Biorąc pod uwagę potrzeby socjalne społeczeństwa polskiego, niedoskonałość rynku pracy i ilość emigracji ukraińskiej, sprzeciw wobec przyjmowania uchodźców pochodzenia arabskiego i afrykańskiego może być pewnym wytłumaczeniem dla negatywnej postawy wobec uchodźców, z drugiej strony takie argumenty można też uznać za niewystarczające.

Ostatnim państwem z Grupy Wyszehradzkiej są Czechy, niewielkie państwo z ludnością około 10,5 mln osób, najwyższym PKB z całej czwórki i wielkimi inwestycjami korporacji międzynarodowych. Są państwem w miarę jednorodnym etnicznie, $\mathrm{z}$ wciąż zwiększającym się wzrostem gospodarczym. Sami Czesi twierdzą, że w obrębie Grupy to u nich są najlepsze zarobki i najwyższa stopa życiowa. Ciężko znaleźć uzasadnienie sprzeciwu wobec relokacji, można się go dopatrywać raczej w egoizmie ekonomicznym, wygodnictwie i solidarności z grupą (państwami GW).

16 D. Puszczykowski, Romowie na Słowacji, http://www.romowie.com/romowie/ ra7_romowie_na_slowacji.pdf (dostęp: 6.09.2019). 


\section{Wypowiedzi przedstawicieli rządu polskiego w mediach na temat kryzysu migracyjnego}

Od objęcia władzy w Polsce przez Prawo i Sprawiedliwość (wygrane wybory prezydenckie i parlamentarne w 2015 r.) stosunki z Unią Europejską sukcesywnie się pogarszają, co odbija się szerokim echem w mediach prawie na całym świecie. Eurosceptyczność aktualnego obozu władzy, opozycja wobec byłego premiera Donalda Tuska, zajmującego aktualnie ważne stanowisko w strukturach unijnych, a także odradzanie się ruchów narodowych prezentujących hasła ksenofobiczne stawia Polskę w kłopotliwej sytuacji i rodzi coraz większą krytykę na forach międzynarodowych. Wystarczy sięgnąć do zaledwie kilku wybranych wypowiedzi przedstawicieli rządu RP $\mathrm{z}$ ostatnich trzech lat, aby uwidocznić niezmienne, a wręcz radykalizujące się stanowisko władz pogarszające obraz Polski we współczesnym świecie. Tematyka relokacji uchodźców jest tutaj doskonałym przykładem.

Premier Beata Szydło na konferencji prasowej z marca 2017 r. tak skomentowała konieczność relokacji uchodźców: „Grupa Wyszehradzka, również Polska, nigdy nie zgodzą się na szantaż i nie zgodzą się na dyktowanie takich warunków. Grupa Wyszehradzka i Polska na pewno nie ulegnie takim dyktatom. (...) Wypowiedzi komisarza i ministrów, którzy z różnych państw UE próbują narzucić taki dyktat i taki szantaż są nieporozumieniem; one nie służą budowaniu jedności Unii Europejskiej"17.

Nieco wcześniej, bo w 2016 r., ówczesny minister spraw wewnętrznych i administracji Mariusz Błaszczak w dość wymijający sposób, jednak nieco bardziej dyplomatyczny od pani premier, radził sobie z takimi pytaniami: „Nie przyjmiemy nikogo, kto by zagrażał bezpieczeństwu. Nie ma w tym momencie ludzi, o których moglibyśmy powiedzieć, że bezpieczeństwu nie zagrażają (...) co do których mielibyśmy 100-procentową pewność, że nie zagrażają bezpieczeństwu. Niestety bardzo wiele z tych osób posługiwało się fałszywymi dokumentami, a więc my nie zrobimy niczego, co by zagroziło bezpieczeństwu Polski i Polaków"18. Mówił też, że uchodźcom trzeba pomagać na miejscu, w Libanie, Turcji, Jordanii, oraz przypomniał o polskich oficerach pomagających na granicach w Grecji i Macedonii.

W innym wystąpieniu w $2017 \mathrm{r}$. Błaszczak powiedział: „W naszej ocenie taki mechanizm jak relokacja uchodźców nie rozwiązuje kryzysu migracyjnego, ale wręcz potęguje. Zachęca kolejne fale migrantów z Afryki czy Azji, aby przyjeżdżali do Europy. Stanowi również potężne źródło dochodu dla

17 Szydło: Polska nie zgodzi się na szantaż ws. uchodźców, Gazeta Prawna.pl, https://www.gazetaprawna.pl/artykuly/1030890,szydlo-polska-nie-zgodzi-sie-na-szantaz-ws-uchodzcow.html (dostęp: 6.09.2019).

18 Mariusz Błaszczak o uchodźcach: nie przyjmiemy nikogo, kto zagrażałby bezpieczeństwu, WP wiadomości, https://wiadomosci.wp.pl/mariusz-blaszczak-o-uchodzcach-nie-przyjmiemy-nikogo-kto-zagrazalby-bezpieczenstwu-6027386168157313a (dostęp: 6.09.2019). 
handlarzy ludźmi. (...) Wywieranie presji na polski rząd w sprawie przyjmowania uchodźców to prosta droga do społecznej katastrofy. W ciągu kilkudziesięciu lat Warszawa może wyglądać jak Bruksela"19. Chodziło mu o zagrożenia i żołnierzy na ulicach Brukseli, jednak ciężko nie zakwalifikować tej wypowiedzi jako ksenofobicznej, szczególnie przy użyciu określeń typu „społeczna katastrofa”.

Tygodni „Newsweek Polska” w czerwcu 2017 r. przedstawił wywiad z Błaszczakiem, który wyśmiewał pomysły przedstawicieli innych krajów unijnych: „- Zachód Europy nie ma pomysłu, jak sobie z tym [imigracją z krajów muzułmańskich - przyp. red.] poradzić - perorował minister Błaszczak. - W ostatni czwartek byłem w Luksemburgu, rozmowa z ministrami spraw wewnętrznych, wie Pan, jaki pomysł mają ważni politycy z zachodu Europy? Otóż chcą integrować poprzez sport, bojowników, muzułmańskich, tych, którzy są gotowi zabić siebie i zabić innych chcą integrować przez sport - oburzał się" i w kolejnym zdaniu obarczał obowiązkiem pomocy uchodźcom inne państwa, zwalniając z niego Polskę: „Zachód spłaca teraz długi wobec Afryki i Azji zaciągane przez setki lat imperialnej polityki kolonialnej prowadzonej na tych kontynentach. - To są rachunki, które były zaciągane przez tamte państwa, a dziś jest próba przerzucenia spłaty tych rachunków również na Polskę. To jest nieuczciwe, to jest niezgodne z obowiązującymi regułami i my przeciwko temu występujemy"20. Ten ostatni argument brzmi już całkiem absurdalnie, wobec wyzwań XXI w.

Ostatnim i najbardziej kuriozalnym zdarzeniem medialnym był spot wyborczy Prawa i Sprawiedliwości przygotowany na potrzeby wyborów samorządowych w $2018 \mathrm{r}$. Wywołał on krytykę również w obozie władzy. W spocie przedstawiono Polskę w 2020 r. jako kraj, w którym emigranci dopuszczają się gwałtów i przemocy. Takiej sytuacji, według autorów kampanii, może zapobiec tylko Prawo i Sprawiedliwość. Odpowiednim komentarzem do tego wydarzenia jest choćby headline artykułu w „Newsweeku Polska”: „Spot PiS straszący uchodźcami wzbudził jednoznacznie negatywne reakcje. Krytykuje go nie tylko opozycja, ale też przedstawiciele środowisk prawicowych, a nawet Krzysztof Bosak z Ruchu Narodowego. Dziennikarka TVP Info domaga się usunięcia jej wizerunku ze spotu. Publicysta Szymon Hołownia pisze na swoim Facebooku: «Ten spot jest obrzydliwie antyludzki (...) i antychrześcijański w postaci czystej». Kto dla odmiany

19 Błaszczak o uchodźcach: „Warszawa może wyglądać jak Bruksela, z żołnierzami na ulicach", WP wideo, https://video.wp.pl/i,blaszczak-o-uchodzcach-warszawa-moze-wygladac-jak-bruksela-z-zolnierzami-na-ulicach,mid,2002539,cid,4051,klip.html?ticaid=11ce1b (dostęp: 6.09.2019).

20 Ł. Rogojsz, Asymilowanie przez chrześcijaństwo i nie tylko. Czyli ministra Błaszczaka problem z muzutmanami, Newsweek Polska, https://www.newsweek.pl/polska/ polityka/szef-mswia-mariusz-blaszczak-o-imigrantach-i-uchodzcach/th6sqcq (dostęp: 6.09.2019). 
aprobuje jego wymowę? Rządzący. Już 40 prominentnych polityków PiS udostępniło go na swoich profilach w mediach społecznościowych"21.

Spot wywołał burzę w mediach, krytykowana była cała partia, a także jego producenci oraz pojedynczy politycy, którzy udostępnili go na swoich profilach w mediach społecznościowych ${ }^{22}$. Jednak pomimo wszechobecnej krytyki zdarzenie to nie wpłynęło negatywnie na sondaże PiS przed wyborami.

\section{Statystyki dotyczące pomocy udzielonej migrantom przez polską administrację}

Pomimo sprzeciwu wobec unijnych kwot przyjmowania uchodźców Polska corocznie nadaje ten status pewnym grupom ludzi, jednak są to dużo mniejsze liczby, niż przewidywał plan UE. Dla porównania poniżej przedstawiono też statystykę z 2014 r., podczas pracy rządu Ewy Kopacz z Platformy Obywatelskiej, oraz późniejsze, po objęciu władzy przez Prawo i Sprawiedliwość z Beatą Szydło na czele rządu.

1. 2014 r. - całkowita liczba osób starających się o status uchodźcy wyniosła 6625. Największą grupę stanowiły osoby z Rosji i Ukrainy. Status uchodźcy otrzymały 262 osoby, a pozostałe formy (ochronę uzupełniającą i pobyt tolerowany) zastosowano wobec 470 osób. Przeważały wśród nich osoby z Syrii i Rosji.

2. 2015 r. - status uchodźcy chciało uzyskać 12325 osób, najwięcej z Rosji (w tym Czeczenii) i Ukrainy. Status uchodźcy otrzymało 348 osób, pozostałe formy zastosowano wobec 289 osób, głównie z Syrii i Rosji.

3. 2016 r. - 12321 osób wnioskujących, najwięcej z Rosji, Ukrainy i Tadżykistanu. Status uchodźcy otrzymało 108 osób, pozostałe formy zastosowano wobec 199 osób, głównie z Rosji, Ukrainy i Syrii.

4. 2017 r. - 5078 osób wnioskujących, najwięcej z Rosji (w tym Czeczenii) i Ukrainy. Status uchodźcy otrzymało 150 osób, inne formy pomocy przyznano 359 osobom, najwięcej z Ukrainy i Rosji ${ }^{23}$.

21 A. Kiedrzynek, Spot PiS o uchodźcach oburzył (prawie) wszystkich. Krytykuje go nawet Krzysztof Bosak, https://www.newsweek.pl/polska/polityka/spot-pis-o-uchodzcach-oburzyl-prawie-wszystkich-krytykuje-go-nawet-krzysztof-bosak/eprtwbc (dostęp: 6.09.2019).

22 Więcej na: Gowin wstydzi się spotu wyborczego PiS o uchodźcach: To jedna $z$ przyczyn nie tak zdecydowanego zwycięstwa w wyborach, dziennik.pl, https://wiadomosci.dziennik.pl/polityka/artykuly/583847,gowin-wstyd-spot-uchodzcy-wybory-pis. html (dostęp: 6.09.2019) i P. Burakowski, Wiemy, kto stoi za ksenofobicznym spotem PiS. To ludzie... Morawieckiego, na Temat, https://natemat.pl/253071,spot-pis-o-uchodzcach-wiemy-kto-odpowiada-za-skandaliczne-nagranie (dostęp: 6.09.2019).

23 Więcej na: https://udsc.gov.pl/ (dostęp: 6.09.2019). 
W latach 2013-2018 nastąpił siedmiokrotny wzrost liczby dokumentów wydawanych cudzoziemcom w związku z pracą w Polsce, co dotyczyło głównie migrantów zarobkowych z Ukrainy ${ }^{24}$.

Warto jeszcze nadmienić, że w Polsce mieszka aktualnie ponad $2 \mathrm{mln}$ obywateli Ukrainy, którzy nie posiadają żadnego z wymienionych wyżej statusów ani nie starają się o niego. Są pracownikami lub rodzinami pracowników w polskich przedsiębiorstwach i przebywają w Polsce dzięki możliwości legalnego okresowego zatrudniania i rozszerzenia ich pobytu ponad przyznawany dawniej pobyt turystyczny ${ }^{25}$.

\section{Podsumowanie}

Mogłoby się wydawać, że XXI w. nie będzie obarczony aż tyloma konfliktami, w większości zbrojnymi, po bardzo gorzkich doświadczeniach XX w. Jednak oczekiwana stabilizacja nie potrwała długo. W wielu częściach świata toczą się może drobne, ale bardzo krwawe konflikty. Afganistan, Irak, Syria i Ukraina to najgłośniejsze miejsca, w których trwa wojna, ale nie wszystkie. W tych konfliktach cierpią rzesze niewinnych ludzi. Dlatego państwa demokratyczne czują się w obowiązku udzielić pomocy poszkodowanej lub zagrożonej ludności, a także podejmować próby rozwiązania lub załagodzenia konfliktów. Już w 1948 r. w Powszechnej Deklaracji Praw Człowieka, jednym z największych osiągnięć ONZ, zapisano konieczność udzielania azylu osobom wymagającym takiej formy pomocy.

Tym bardziej nie na miejscu wydają się przejawy neofaszyzmu, ksenofobii, homofobii i próby zapobiegania tworzeniu się społeczeństw wielokulturowych. Dzieje się tak przez nieodpowiednio prowadzoną politykę, podsycanie strachu i tolerowanie przestępczości.

Polska polityka od 2015 r. stanowi podręcznikowy przykład niedostosowania do potrzeb współczesnej międzynarodowej rzeczywistości. Znalezienie sobie największego partnera i zwolennika w osobie premiera Węgier chyba nie było dobrym pomysłem. A. Czyż w swojej pracy pokazała sytuację nie tylko węgierską, ale w czytelny sposób odnosi się do sytuacji w Polsce: „Obawy wyrażane przez polityków w państwach Grupy Wyszehradzkiej podziela duża część społeczeństw we wszystkich czterech wyszehradzkich krajach Europy Środkowej. Partie w nich rządzące wykorzystują te lęki i nastroje społeczne, intensyfikują retorykę antyislamską i antyimigracyjną, aby zdobyć w ten sposób poparcie wyborców. Na Węgrzech zdecydowana postawa premiera Viktora Orbána w obliczu fali uchodźców przyczyniła się do przezwyciężenia przez rządzący Fidesz kryzysu poparcia i umocnienia

24 A. Górny, M. Kindler, Cudzoziemcy w Polsce na przełomie XX i XXI wieku [w:] 25 wykładów o migracjach..., s. 221.

25 Nawet milion pracowników może wyjechać z Polski. Czarny scenariusz, https:// tvn24bis.pl/z-kraju,74/ukraincy-moga-wyjechac-z-polski-niemcy-otwieraja-rynek-pracy,895051.html, tvn24bis (dostęp: 6.09.2019). 
się na pozycji lidera sondaży, a kryzys migracyjny zdominował węgierską debatę publiczną, odsuwając na bok inne tematy, gdyż stanowcza retoryka premiera wpisuje się w nastroje społeczne"26.

$\mathrm{Z}$ drugiej strony trzeba jednak zwrócić uwagę na koszty przyjęcia deklarowanych przez wcześniejszy rząd ok. 10 tys. uchodźców. Niedomagania polskiego systemu ubezpieczeń społecznych i polityki socjalnej, niskie wynagrodzenia (w porównaniu z zachodnimi państwami europejskimi) oraz znaczne otwarcie się na migrację z Ukrainy mogą w niewielkim stopniu usprawiedliwiać podejście rządu. Większość polskiego społeczeństwa także nie akceptuje przyjmowania uchodźców, mogłoby to więc wywołać wewnętrzne protesty.

Może w dłuższym etapie, bardziej ewolucyjnym, a nie rewolucyjnym, zmiany podejścia i postrzegania będą możliwe. Przykład jednak musi iść z góry, od rządu, parlamentu, polityków, kleru, celebrytów oraz ekspertów.

\section{Bibliografia}

25 wykładów o migracjach, M. Lesińska. M. Okólski (red.), Warszawa 2018.

Błaszczak o uchodźcach: „Warszawa może wygladać jak Bruksela, z żolnierzami na ulicach", WP wideo, https://video.wp.pl/i,blaszczak-o-uchodzcach-warszawa-moze-wygladac-jak-bruksela-z-zolnierzami-na-ulicach,mid,2002539,cid,4051, klip.html?ticaid=11celb.

Burakowski P., Wiemy, kto stoi za ksenofobicznym spotem PiS. To ludzie... Morawieckiego, na Temat, https://natemat.pl/253071,spot-pis-o-uchodzcach-wiemy-kto-odpowiada-za-skandaliczne-nagranie.

Gowin wstydzi się spotu wyborczego PiS o uchodźcach: To jedna z przyczyn nie tak zdecydowanego zwycięstwa w wyborach, dziennik.pl, https://wiadomosci. dziennik.pl/polityka/artykuly/583847, gowin-wstyd-spot-uchodzcy-wybory-pis.html.

Czyż A., Państwa Grupy Wyszehradzkiej wobec kryzysu migracyjnego, „Studia Politicae Universitatis Silesiensis" 2017, t. 18.

Dudek A., Historia polityczna Polski 1989-2015, Kraków 2015.

Gędek M., Nieznane dzieje Polski 1943-2015, Warszawa 2016.

Gniazdowski M., Jaroszewicz M., Węgierska odsłona kryzysu migracyjnego. Analizy OSW, 2015, https://www.osw.waw.pl/pl/publikacje/analizy/2015-09-09/ wegierska-odslona-kryzysu-migracyjnego.

Joint Statement on Migration, Praga, 2016, http://www.visegradgroup.eu/calendar/2016/jointstatementon.

Kiedrzynek A., Spot PiS o uchodźcach oburzył (prawie) wszystkich. Krytykuje go nawet Krzysztof Bosak, https://www.newsweek.pl/polska/polityka/spot-pis-o-uchodzcach-oburzyl-prawie-wszystkich-krytykuje-go-nawet-krzysztof-bosak/eprtwbc.

Mariusz Błaszczak o uchodźcach: nie przyjmiemy nikogo, kto zagrażałby bezpieczeństwu, WP wiadomości, https://wiadomosci.wp.pl/mariusz-blaszczak-o-uchodz-

26 A. Czyż, Państwa Grupy Wyszehradzkiej..., s. 154. 
cach-nie-przyjmiemy-nikogo-kto-zagrazalby-bezpieczenstwu-602738616815 7313a.

Nawet milion pracowników może wyjechać z Polski. Czarny scenariusz, https://tvn24bis.pl/z-kraju,74/ukraincy-moga-wyjechac-z-polski-niemcy-otwieraja-rynek-pracy,895051.html, tvn24bis.

Princ M., Ochrona uchodźców w Polsce [w:] Uchodźcy w Europie. Uwarunkowania, istota, następstwa, K.A Wojtaszczyk, J. Szymańska (red.), Warszawa 2017.

Piasecki A., Michalak R., Polska 1945-2015, Warszawa 2016.

Puszczykowski D., Romowie na Słowacji, http://www.romowie.com/romowie/ra7_ romowie_na_slowacji.pdf.

Rogojsz Ł., Asymilowanie przez chrześcijaństwo i nie tylko. Czyli ministra Błaszczaka problem z muzutmanami, Newsweek Polska, https://www.newsweek.pl/ polska/polityka/szef-mswia-mariusz-blaszczak-o-imigrantach-i-uchodzcach/ th6sqcq.

Szydło: Polska nie zgodzi się na szantaż ws. uchodźców, Gazeta Prawna.pl, https:// www.gazetaprawna.pl/artykuly/1030890,szydlo-polska-nie-zgodzi-sie-naszantaz-ws-uchodzcow.html.

Akty prawne

Konwencja dotycząca statusu uchodźców, sporządzona w Genewie dnia 28 lipca 1951 r., Dz.U. z 1991 r. Nr 119, poz. 515 ze zm.

Konstytucja Rzeczypospolitej Polskiej z dnia 2 kwietnia 1997 r., Dz.U. z 1997 r. $\mathrm{Nr} 78$, poz. 483 ze zm.

Ustawa z dnia 13 czerwca 2003 r. o udzielaniu cudzoziemcom ochrony na terytorium Rzeczypospolitej Polskiej, tekst jedn.: Dz.U. z 2019 r. poz. 1666 ze zm.

Ustawa z dnia 7 września 2007 r. o Karcie Polaka, tekst jedn.: Dz. U. z 2019 r. poz. 1598 ze zm.

\section{Streszczenie}

W historii Polski fale przybywających migrantów wzmacniały potencjał państwa (XVI w.). W XIX i XX w. emigracje Polaków (w tym także narodowości żydowskiej) wpływały negatywnie na sytuację polityczną i gospodarczą Polski. Jednak problem migrantów, który wystąpił po 2015 r., stanowi zupełnie nowe doświadczenie. Polska administracja działa w sprawach migrantów na podstawie regulacji prawnych, które są racjonalne i spójne. Umożliwiają one zastosowanie standardów UE w Rzeczpospolitej Polskiej. Sytuację migrantów w Polsce i stosunek Polaków do nich określa jednak w największym stopniu polityka rządzącej partii (Prawo i Sprawiedliwość). Cechuje ją ksenofobia, która uniemożliwia racjonalne rozwiązanie problemów. W dodatku politycy tej partii często wyolbrzymiają problem migrantów dla osiągnięcia doraźnych korzyści (np. wyborczych).

Słowa kluczowe: rząd, ustawy, polityka, migranci, Unia Europejska, Grupa Wyszehradzka, Polska 
Polish Administration and Migration after 2015: Key Legal and Political Aspects

Abstract

Over the course of Polish history, successive waves of migrants strengthened the country's potential (16th century). In the 19th and 20th centuries, the emigration of Poles (including those of Jewish origin) had a negative impact on Poland's politics and economy. Yet the post-2015 migration issue is an entirely new experience indeed. As regards migrants, the Polish state administration operates on the basis of reasonable and coherent regulations which provide for the application of the EU standards in the Republic of Poland. The situation of migrants in Poland and the Poles' attitude towards them is mostly defined by the politics of the ruling party (Law and Justice). It is characterised by xenophobia, which makes reasonable problem-solving impossible. In addition, the party's politicians often exaggerate the migrant problem in order to ensure ad hoc gains (e.g. on the voting day).

Keywords: government, acts of law, politics, migrants, European Union, Visegrad Group, Poland 